\title{
THE INFLUENCE OF SOCIO-ECONOMIC AND NUTRITIONAL CHARACTERISTICS ON CHILD GROWTH IN KWALE DISTRICT OF KENYA
}

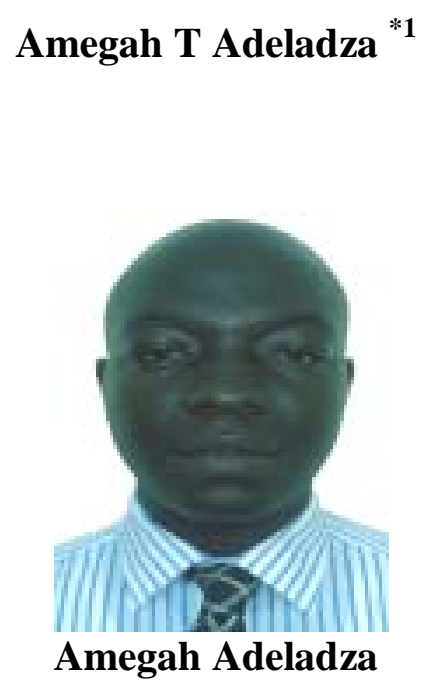

*Corresponding author email: raskofiadel@yahoo.com

${ }^{1}$ Department of Human Biology, School of Biological Sciences, University of Cape Coast, Cape Coast, Ghana. 


\section{ABSTRACT}

Child malnutrition remains a serious public health problem in Kwale District of Kenya. Data on the levels and patterns of malnutrition and on the factors perpetuating poor nutritional status in the District is lacking, making it extremely difficult to plan appropriate interventions to help reduce the levels of child malnutrition in Kwale District. A total of 300 households and 300 children aged 12-23 months were surveyed in four locations in the Samburu and Kinango Divisions of Kwale District. Anthropometric methods and structured questionnaires were used to determine the nutritional status of the children. The relative importance of demographic and socioeconomic factors, as well as prevailing child health and nutrition practices on the growth and survival of children in the District were also determined. Measuring nutritional status by height-for-age and weight-for-age demonstrated a very high percentage of malnourished children. About $34 \%$ of children in the study area were underweight, and 51\% stunted. Of the demographic variables studied, child's age and sex were significant predictors of nutritional status. Boys had worse nutritional status than girls. Age group 20-23 months was found to be the most vulnerable. The household and socio-economic variables strongly associated $(\mathrm{p}<0.05)$ with one or more anthropometric deficits were: geographic location; household size; occupation and education level of mothers; and sex, religion and occupation of household heads.

Nutritional status of children was also found to be significantly associated with immunization and breastfeeding status. The links with breastfeeding practice was however confounded by age of child. Breast-feeding rate was very high in the area, but the introduction of complementary foods starts much too early. Only 5\% of the study children were exclusively breastfed up to the age of 6 months. Demographic and socio-economic factors and improper feeding practices were some of the underlying causes of the poor nutritional status of Kwale children. A range of specific interventions are thus necessary for improving the nutrition and health of children in the area.

Key words: Malnutrition, Growth, Kinango, Samburu, Kwale 


\section{INTRODUCTION}

Major progress has been made over the past few decades in reducing child malnutrition in developing countries. Between 1970 and 1995 the proportion of malnourished children was reduced by $15 \%$ in developing countries [1,2]. In spite of this achievement, $27 \%$ of children under the age of five years in developing countries are still underweight [3]. Malnutrition remains an important predictor of child morbidity and mortality, accounting for more than half of all child deaths worldwide [4]. A strong link exists between increasing severity of anthropometric deficits and increased child mortality. This hypothesis is corroborated by a World Health Organization (WHO) technical report which noted a strong exponential association between the severity of underweight and mortality [5].

Poor growth is associated with impaired development which is apparent in the relationship between growth status, and school performance and intellectual achievement highlighted in a study by Martorell and colleagues [6]. Malnutrition also increases a child's risk of contracting respiratory infections, diarrhoea, measles and other diseases that often kill children or permanently harm their physical, psychosocial and cognitive development [7].

The macro level association between poverty and child malnutrition is well documented with the risk factors for poor nutritional status largely coinciding with the correlates of poverty. Malnutrition is a result of more complex social and behavioural determinants that affect child feeding and rearing [8]. Socioeconomic and environmental conditions, together with feeding practices, are important determinants of malnutrition in developing countries $[9,10]$.

Kwale District has some of the worst socioeconomic and health indicators in Kenya with Kinango and Samburu as the most affected divisions in the district. Child malnutrition also remains a serious public health problem in the District. The Kwale Rural Support Program (KRSP) in 1997 estimated the prevalence of stunting and wasting in the District to be $67.6 \%$ and $39.5 \%$, respectively [11]. Stunting prevalence in Samburu and Kinango Divisions has been estimated to be $44.7 \%$ [12]. Health centres in Kinango and Samburu have also reported 50\% cases of underweight [13].

Data on levels and patterns of malnutrition in Kwale District is limited. It is important to establish the true extent and underlying causes of child malnutrition in Kwale District to help map-out appropriate intervention strategies to reduce the levels of child malnutrition in the District. This study therefore seeks to determine the nutritional status of children in Kwale District and establish the relative importance of demographic and socio-economic factors as well as child nutrition and health practices on the growth and survival of children in Kwale District. 


\section{MATERIALS AND METHODS}

\section{Study Location and Population}

The study was conducted in four locations, namely Kasemeni, Mwavumbo, Mwatate and Mtaa in the Samburu and Kinango Divisions of Kwale District. Kwale District is located in the Coast Province of Kenya and is divided into 6 administrative divisions and 37 locations. The study population comprised all children aged 12-23 months in the four study locations. This age group was chosen because according to the WHO, high prevalence of malnutrition occurs during the post-weaning period (12-23 months) [14].

\section{Sampling Procedures}

The study locations were randomly sampled from the 37 locations in the District. The Expanded Programme of Immunization (EPI) cluster sampling method was used to select 30 communities and 300 households from the study locations.

\section{Anthropometric Measurements and Data Collection}

A structured questionnaire was used to collect demographic and socioeconomic data from the selected households. The height (in $\mathrm{cm}$ ) and weight (in $\mathrm{kg}$ ) of 300 study children in the households visited were measured using a measuring board and a suspended weighing scale respectively. The children were in minimal clothing and without footwear when measurements were taken. The age of the children were obtained from their parents and verified from their birth certificates or baptismal cards where available.

\section{Data Analysis and Statistical Methods}

The SPSS computer programme was used to analyse the collected data. Epi Info was used to classify the study children into categories of nutritional status by converting the anthropometric measurements into z-scores of weight for age (WAZ), height for age (HAZ) and weight for height (WHZ), and compared with Hamill et al. [15] National Center for Health Statistics growth reference data.

The Independent sample t-test was used to compare the mean of one continuous dependent variable for two groups of cases. In comparing the mean for a continuous dependent variable by a single independent variable, a one-way ANOVA was applied, and in determining which means differ, the Tukey Post Hoc test was run. The Chisquare test was employed to investigate the association between two categorical variables. The association between two continuous variables was investigated using linear regression. The Univariate Analysis Model was used to adjust for potential confounders. Significance level was set at 5\%

\section{RESULTS}

\section{Demographic and socioeconomic characteristics}

About $94 \%$ of household heads in the study area were males. Majority (72\%) of household heads were Muslims. Farming was the dominant occupation of household

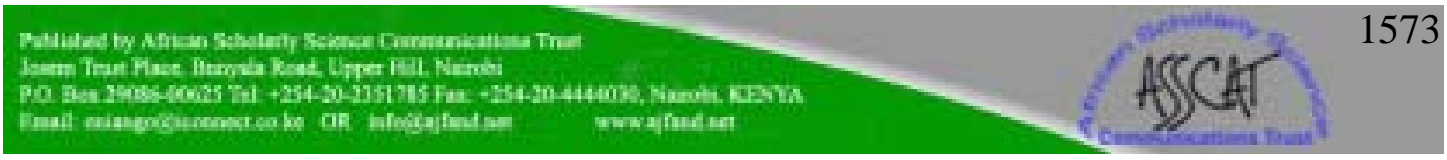


heads. The difference between the study locations in relation to the occupation of household heads was significant $(\mathrm{p}<0.05)$ [Table 2]. About 53\% of the mothers surveyed were aged between 16 and 25 years. More than half $(59 \%)$ of the mothers were housewives. About $62 \%$ of the mothers had no formal education. There was a significant difference between the locations with respect to maternal occupation $(\mathrm{p}<0.05)$ [Table 2]. The highest proportion of study children were found in Kasemeni and in the age group 12-15 months.

\section{Child health and nutrition practices}

Almost all the study children attended growth monitoring. Majority $(81 \%)$ of the children were fully immunized. The proportion of breastfed children was quite high $(81 \%)$. Only $5 \%$ of these breastfed children were exclusively breastfed up to the recommended 6 months. Complementary foods were introduced too early in the area with uji (a thin cereal porridge made from maize flour) being the main supplement given to children. The proportion of children that received supplements by the age of 0 and 3 months was 70\% [Table 3]. There was no significant difference between the locations with respect to all the child health and nutrition practices [Table 4].

\section{Nutritional status of children}

About 7\% of the study children were wasted with Mwavumbo and age group 20-23 months recording the highest proportion of wasted children. One-third of the study children were underweight with Kasemeni and age groups 16-19 and 20-23 months recording the highest underweight rates. About $9 \%$ of the children were severely underweight. Half of the children were stunted with Mtaa and age group 20-23 months recording the highest stunting rates. The proportion of severely stunted children was $22 \%$ [Table 5].

\section{Determinants of child nutritional status}

The difference in nutritional status (HAZ) in relation to the location of a child was significant $(\mathrm{p}<0.05)$. The HAZ of children in Mwavumbo was worse than those in Mwatate $(p<0.05)$ [Table 6]. The slope of the scatter graph in Figure 1 was significantly different $(\mathrm{p}<0.05)$ suggesting nutritional status (WHZ) of children got worse as total household size increased.

Children from female-headed households were worse for WAZ than those from maleheaded households $(\mathrm{p}<0.05)$ [Table 6]. The difference in nutritional status (WHZ) between groups of children defined by occupation of their household head was significant $(\mathrm{p}<0.05)$. Children from households with a mechanical/factory worker head had better WHZ compared to those from households whose heads were either a teacher/office worker or builder/construction worker $(p<0.05)$ [Table 6]. Children in Christian headed households had better nutritional status (WAZ) than those in Muslim headed households $(\mathrm{p}<0.05)$ [Table 6]. Children whose mothers were educated to secondary level had better nutritional status (WAZ) than children of non-educated mothers $(\mathrm{p}<0.05)$. Children of housewives had better WHZ than children of farming mothers $(\mathrm{p}<0.05)$ [Table 6]. 
There was a significant difference in nutritional status (WAZ and HAZ) between boys and girls $(\mathrm{p}<0.05)$ with boys being worse than girls [Table 6]. The difference in nutritional status (HAZ) between the age groups of the children was significant ( $\mathrm{p}<0.05$ ). Children aged 12-15 months had better HAZ compared to those aged 20-23 months $(\mathrm{p}<0.05)$ [Table 6]. Breastfed children had better nutritional status (HAZ) compared to non-breastfed children $(\mathrm{p}<0.05)$ [Table 6]. Child's age was however found to be confounding the association [Table 7]. Fully immunized children had better nutritional status (WAZ and HAZ) than partially immunized children.

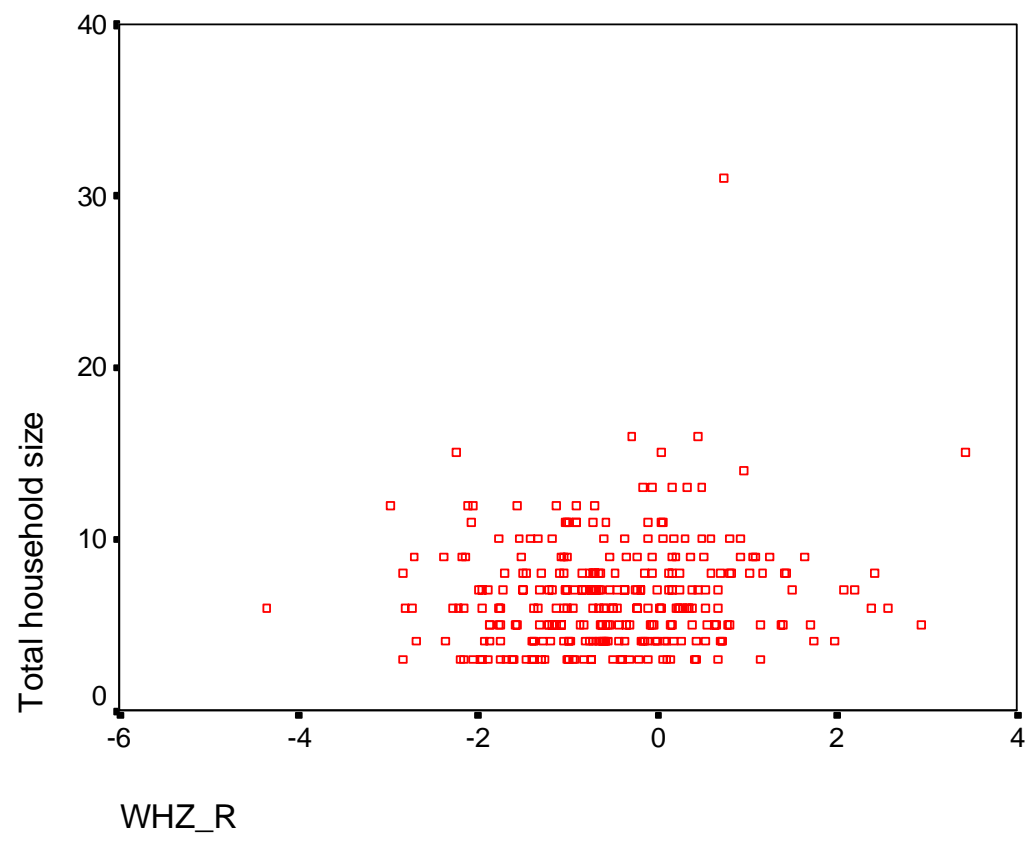

Figure 1: Scatter diagram of the association between nutritional status and total household size

Using linear regression model, the intercept and slope of the graph was 6.8 and 0.34 respectively. The p value for the slope (0.039) was significant.

\section{DISCUSSION}

\section{Child Nutritional Status}

The prevalence of underweight and stunting in the study area is very high as per the WHO classification for assessing severity of malnutrition by prevalence range among children under five [1].Wasting prevalence on the other hand, according to this index, can be classified as medium, but using the WHO severity index for malnutrition in emergency situation [5], prevalence of wasting in the study area is high, with the prevalence levels recorded in Mwavumbo considered as serious. 
Kwale District is known to have very high food insecurity levels and experiences long periods of increased food deficit due to the erratic rainfall pattern in the District which affects crop production and results in severe crop failure up to about $75 \%$ [16]. Kinango and Samburu are the worst affected divisions in the district. Wildlife is another big constraint to food production in the two divisions with elephants from the Shimba Hills Game Reserve and Tsavo National Park straying to destroy maize plantation in Kinango and Samburu [13]. Baboons and wild pigs also contribute to crop destruction in the two divisions. The foods available in Kwale households are also of poor nutritional quality due to the over-production and dependence on maize and cassava, and the low income levels of households which inhibits them from purchasing protein and vitamin rich foods [17]. These factors can adversely affect child nutritional status and together with other socioeconomic factors contribute to the poor nutritional status of the study children.

Stunting prevalence in the study area increased with age, which according to literature [18], reflects extended periods of inadequate food intake and increased morbidity of the past years. The major livelihood in Samburu and Kinango are livestock rearing and crop production. It is known from literature $[13,16]$ that crop production in these divisions is hampered by successive rain failure and drought. Their livestock also often perish from extreme weather conditions, water scarcity, and dry and scanty pasture. According to a report [16], about $94 \%$ of households in affected communities therefore resort to reduction in quantity and regularity of meals as coping mechanisms. Majority (74\%) of households also skip meals for an entire day on some occasions. This situation predisposes household members, especially children, to a vicious cycle of hunger and illness, which could account for why stunting increases with age in the area. Boys were more likely to be malnourished than girls in the study area $(\mathrm{p}<0.05)$, which is consistent with several other studies, and according to WHO [1], is quite common in the absence of discriminatory practices.

Children aged 20-23 months were the most vulnerable to malnutrition in the study area, which indicates the vulnerability of children during the weaning transition. Malnutrition rises rapidly and becomes common during the weaning transition. A study reported that at 2 years of age children begin to receive less intensive care, freeing the principal caretakers (mostly mothers) for economic activities outside the household [19]. This practice can have adverse effect on a child's nutrition status depending on his/her age. An important factor under these circumstances is the frequency of feeding. A study in Western Tanzania [20], reported that women spent less time cooking and feeding their children during the peak labour seasons, and further went on to state that, preparing a child's food separately requires time and extra firewood for cooking which many rural mothers cannot afford, hence the frequency of a child's feeding depends on the number of times the family takes its meals. In developing countries, mothers were traditionally known to cook their children's food before leaving for their economic activities, but it seems this practice is dying out as highlighted by a situational analysis in Malawi [21]. 


\section{Demographic and Socio-economic Predictors of Nutritional Status}

The geographic location of a child is an important determinant of his/her nutritional status. Numerous studies have found children in rural and remote areas to be more likely to be stunted than their counterparts in urban areas. Stunting is also known to be more pronounced in locations where economic conditions are poor [18]. The remoteness and the extremely poor socio-economic conditions of the study area could therefore be a contributing factor to the high level of stunting in the area.

Children in female-headed households were more likely to be underweight than their counterparts in male-headed households $(\mathrm{p}<0.05)$, which could be attributed to extreme poverty in female-headed households. The Kenya Welfare Monitoring Survey III found female-headed households in Kenya to exhibit high levels of poverty [22].

The religious affiliation of a household head has strong connotation for child nutritional status. The majority of Muslim heads in the study area own cattle. Studies have found the ownership of cattle to be positively associated with better child nutritional status [23, 24]. Ironically, this study found children in Muslim households to be more likely to be underweight than their counterparts in Christian households $(\mathrm{p}<0.05)$. Studies conducted in Kenya $[25,26,27]$ found the majority of milk produced by dairy cows to be sold. Two studies $[26,27]$ further reported that the main reason for dairy cow ownership in Kenya is to produce milk for sale and not for household consumption. This practice has obvious implications for household nutritional status because households sell food with better micronutrient bioavailability than locally available substitutes, and also the income raised is sometimes spent on non-food items. A report also found milk yield in Kwale households (0.5- 1.5 litres per cattle per day) to be insignificant due to the type of cattle (Zebu) kept [13]. The poor nutritional status of children from Muslim households in the study area could therefore be attributed to these factors.

The occupation of household heads and mothers appears to be the major factor influencing the level of wasting in the study area. A child whose household head was a mechanical/ factory worker was better nourished than a child whose household head was in a different trade. The association was however not significant for all occupations except teaching/office work and building/construction work. This finding could be due to mechanical/factory work being a high income generating activity than other jobs in the area. Also children of farming mothers were more likely to be wasted than children whose mothers were housewives $(\mathrm{p}<0.05)$, and this could be due to the fact that in developing countries, mothers who leave home to farm or undertake other economic activities often leave their young children in the care of older siblings, neighbours or relatives who often do not provide optimal childcare. Care is, however, increasingly recognized as an important determinant of child nutritional status as highlighted by a study in Ghana [28]. Farming mothers in the study area also rely solely on produce from their farms to meet household food needs leading to a monotonous maize and cassava-base diet in households. Farming mothers are also

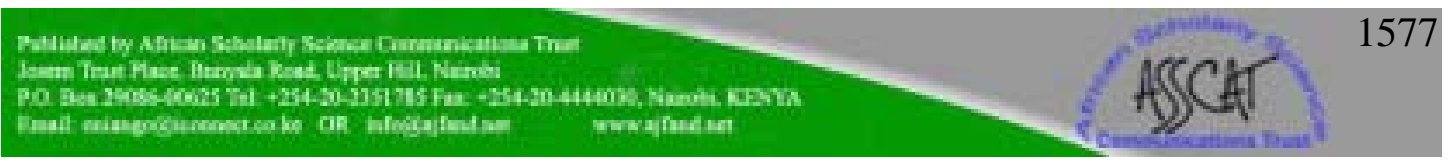


compelled to sell the bulk of protein and vitamin rich crops they harvest from their farms for cash due to the high demand and good prices of these produce in the area with the money raised often spent on non-food items. These practices also contribute to the poor nutritional status of children of farming mothers.

Mother's education is closely linked to nutritional status of children. Children of noneducated mothers are more likely to be underweight than those of secondary-educated mothers $(\mathrm{p}<0.05)$ which is consistent with numerous studies showing the importance of maternal education for child health and nutrition. Mishra and Retherford [29] found maternal education to have a strong independent effect on child nutritional status even after controlling for the confounding effect of twelve other demographic and socioeconomic variables. Smith and Haddad [2] also identified improvement in female secondary school enrollment rates as responsible for $43 \%$ of the $15.5 \%$ reduction in child underweight rates in developing countries during the period 197095.

Large household size is a well documented risk factor for child malnutrition in developing countries. The study found children from large households to be more likely to be wasted. Resources available to large households are inadequate to buffer children from the problems of maintaining large families such as competition for limited food and could account for the finding of this study.

\section{Child Health and Nutrition Practices}

Feeding practices are the underlying determinants of child nutritional status. Breast milk provides all the necessary nutrients and anti-infective properties needed by a child in the first 6 months of life. Although the majority of infants in developing countries are breastfed, exclusive breastfeeding for the recommended period of 6 months is rare, which was a common occurrence in the study area. Child nutritional status is compromised where exclusive breastfeeding is not practiced. The study found breastfed infants to be less likely to be stunted than their non-breastfed counterparts $(\mathrm{p}<0.05)$. Child's age was however found to confound the association.

Complementary foods were introduced much earlier than recommended in the study area, and in some cases, were given as early as the day of birth. During the first 3 months, they were given to about $70 \%$ of the children. It's possible that because of the high prevalence of malnutrition in the study area, mothers misguidedly introduce complementary food very early to prevent their children from being malnourished. It's also possible that mothers who express anxiety about the adequacy of their milk flow might be wrongly advised about the early introduction of complementary feeding.

Possession of a health book and attendance to growth monitoring is an indicator of proper child health and nutrition care. When mothers send their children for growth monitoring they receive food supplements and are offered information on proper child feeding practices. Almost all the children attended growth monitoring. Only 84\% of these children were however in possession of a health book. No association was

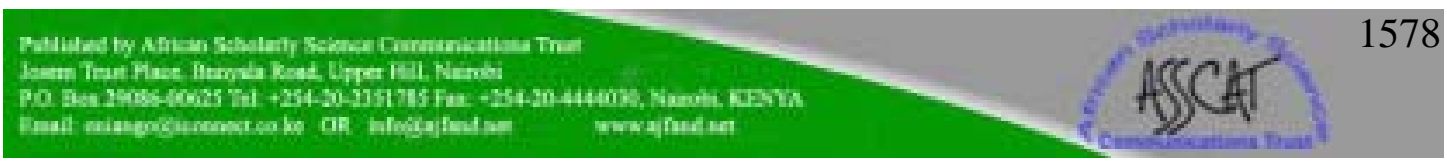


found between level of stunting and possession of a health book, which is contrary to the findings of a study in Indonesia [30] that found children possessing a health card to have better HAZ than children without a health card.

Immunization status emerged as a significant predictor of a child's linear growth in the study area. Immunized children were less likely to be malnourished than nonimmunized children $(\mathrm{p}<0.05)$, an association that remained significant even after controlling for the confounding effect of child's age.

\section{CONCLUSION}

The study reveals the pervasiveness of child malnutrition in Kwale District with chronic malnutrition more pronounced in the area. Demographic and socio-economic parameters such as occupation and educational level of mothers; gender and occupation of household heads; and household size were strongly associated with child nutritional status in the study area. Inappropriate child feeding practices such as early cessation of breastfeeding and early introduction of complementary foods predominates in the area and also contributes to the poor nutritional status of children in Kwale District. 
Table1: Demographic and Socioeconomic Characteristics of Children

\begin{tabular}{lr}
\hline Variable & Proportion (\%) \\
\hline Sex of children & \\
Males & 49.3 \\
Females & 50.7
\end{tabular}

Age of children

12-15 months

16-19 months

20-23 months

\section{Location of children}

Mwavumbo

Mwatate

Kasemeni

Mtaa

Sex of household heads

Males

Females

Religion of household heads

Muslim

Christian

Other

Occupation of household heads

Teacher/Office worker

Fisherman/Trader

Farmer

Builder/Construction worker

Mechanical/Factory worker

9.3

Other

Marital status of mothers

Never married

Married

Divorced/Separated

Widowed

\section{Age of mothers}

16-25yrs 
Education level of mothers

None

Primary

Secondary

Occupation of mothers

Housewife

Farmer

Other

Table 2: Association between study location and socioeconomic characteristics of children

\begin{tabular}{|l|r|r|}
\hline Variable & Chi square $\left(\mathbf{X}^{2}\right)$ value & p value \\
\hline Sex of household heads & 1.07 & 0.784 \\
\hline Religion of household heads & 5.636 & 0.465 \\
\hline Occupation of household heads & 28.966 & 0.016 \\
\hline Marital status of mothers & 9.999 & 0.351 \\
\hline Age of mothers & 5.281 & 0.508 \\
\hline Education level of mothers & 11.229 & 0.082 \\
\hline Occupation of mothers & 19.397 & 0.004 \\
\hline
\end{tabular}


Table 3: Child Health and Nutrition Practices

\begin{tabular}{lr}
\hline \hline Variable & Proportion (\%) \\
\hline Possession of health book & 83.7 \\
Yes & 16.3 \\
No & \\
Attendance to growth monitoring & \\
Yes & 99.0 \\
No & 1.0 \\
Immunization status & \\
Fully immunized & 81.2 \\
Partially immunized & 18.8 \\
Breastfeeding status & \\
Breastfed & \\
Not breastfed & 80.7 \\
Age at introduction of complementary food & 19.3 \\
0-3 months & \\
4-6 months & \\
$7-12$ months & 69.7 \\
\hline \hline
\end{tabular}

Table 4: Association between study location and child health and nutrition practices

\begin{tabular}{|l|r|r|}
\hline Variable & $\mathbf{X}^{2}$ value & p value \\
\hline Possession of health book & 3.425 & 0.142 \\
\hline Attendance to growth monitoring & 1.263 & 0.738 \\
\hline Immunization status & 4.516 & 0.211 \\
\hline Breastfeeding status & 0.938 & 0.816 \\
\hline Age at introduction of complementary & & \\
food & 1.195 & 0.977 \\
\hline
\end{tabular}




\section{Table 5: Nutritional Status of Children}

\begin{tabular}{|c|c|c|c|c|c|}
\hline Variable & $\begin{array}{l}\% \\
\text { Wasted }\end{array}$ & $\begin{array}{l}\% \\
\text { Underweight }\end{array}$ & $\begin{array}{l}\text { \% Severely } \\
\text { underweigh } \\
\text { t }\end{array}$ & $\begin{array}{l}\% \\
\text { Stunted }\end{array}$ & $\begin{array}{l}\% \\
\text { Severel } \\
\text { y } \\
\text { stunted }\end{array}$ \\
\hline \multicolumn{6}{|l|}{ Location } \\
\hline All locations & 7.3 & 33.7 & 9.3 & 51.3 & 21.7 \\
\hline Mwavumbo & 10.0 & 34.3 & 14.3 & 50.0 & 25.7 \\
\hline Mwatate & 7.5 & 28.8 & 7.5 & 43.8 & 15.0 \\
\hline Kasemeni & 7.0 & 39.0 & 7.0 & 53.0 & 19.0 \\
\hline Mtaa & 4.0 & 30.0 & 10.0 & 62.0 & 32.0 \\
\hline \multicolumn{6}{|l|}{ Age } \\
\hline $\begin{array}{l}\text { months } \\
16-19\end{array}$ & 6.8 & 28.0 & 9.3 & 41.5 & 18.6 \\
\hline $\begin{array}{l}\text { months } \\
20-23\end{array}$ & 6.3 & 37.5 & 8.3 & 52.1 & 24.0 \\
\hline months & 9.3 & 37.2 & 10.5 & 64.0 & 23.3 \\
\hline Sex & & & & & \\
\hline Boys & 9.5 & 41.2 & 13.5 & 59.5 & 24.3 \\
\hline Girls & 5.3 & 26.3 & 5.3 & 43.4 & 19.1 \\
\hline
\end{tabular}

A girl within the age group 12-15 months and from Mwatate was the only child severely wasted

Wasting and severe wasting: WHZ below -2SD and -3SD of NCHS reference population respectively

Underweight and severe underweight: WAZ below -2SD and -3SD of NCHS reference population respectively

Stunting and severe stunting: HAZ below -2SD and -3SD of NCHS reference population respectively 
Table 6: Determinants of Nutritional Status

\begin{tabular}{lrrr}
\hline \hline Variable & \multicolumn{1}{l}{$\begin{array}{l}\text { Mean } \\
\text { WHZ } \pm \text { SD }\end{array}$} & \multicolumn{1}{l}{$\begin{array}{l}\text { Mean } \\
\text { WAZ } \pm \text { SD }\end{array}$} & \multicolumn{1}{l}{$\begin{array}{l}\text { Mean } \\
\text { HAZ } \pm \text { SD }\end{array}$} \\
\hline Geographic location & & & \\
All locations & $-0.51 \pm 1.10$ & $-1.67 \pm 1.01$ & $-2.13 \pm 1.25$ \\
Mwavumbo $^{1}$ & $-0.48 \pm 1.30$ & $-1.80 \pm 1.14$ & $-2.39 \pm 1.27$ \\
Mwatate $^{2}$ & $-0.61 \pm 1.10$ & $-1.54 \pm 0.93$ & $-1.80 \pm 1.34$ \\
Kasemeni & $-0.48 \pm 1.03$ & $-1.65 \pm 0.99$ & $-2.14 \pm 1.15$ \\
Mtaa & $-0.45 \pm 0.92$ & $-1.73 \pm 0.95$ & $-2.29 \pm 1.20$ \\
\hline ANOVA test & $\mathrm{F}=0.316$ & $\mathrm{~F}=0.879$ & $F=3.277$ \\
& $\mathrm{p}=0.814$ & $\mathrm{p}=0.452$ & $p=0.021$ \\
Tukey Post Hoc test & & & $p=0.017^{1 \& 2}$ \\
\hline & & & \\
Sex of household head & & & \\
Both sexes & $-0.51 \pm 1.10$ & $-1.67 \pm 1.01$ & $-2.13 \pm 1.25$ \\
Male & $-0.48 \pm 1.06$ & $-1.63 \pm 1.00$ & $-2.10 \pm 1.25$ \\
Female & $-0.92 \pm 1.47$ & $-2.20 \pm 1.07$ & $-2.54 \pm 1.22$ \\
\hline T test & $\mathrm{t}=1.274$ & $t=2.375$ & $\mathrm{t}=1.473$ \\
& $\mathrm{p}=0.218$ & $p=0.018$ & $\mathrm{p}=0.142$ \\
\hline
\end{tabular}

Occupation of household

head

\begin{tabular}{|c|c|c|c|}
\hline All occupation & $-0.51 \pm 1.10$ & $-1.67 \pm 1.01$ & $-2.13 \pm 1.25$ \\
\hline Teacher/Office worker ${ }^{1}$ & $-0.78 \pm 0.77$ & $-1.71 \pm 0.74$ & $-1.95 \pm 1.20$ \\
\hline Fisherman/Trader & $-0.47 \pm 1.18$ & $-1.73 \pm 1.03$ & $-2.19 \pm 1.29$ \\
\hline Farmer & $-0.48 \pm 1.18$ & $-1.74 \pm 1.05$ & $-2.30 \pm 1.39$ \\
\hline Builder/Construction worker ${ }^{2}$ & $-0.68 \pm 0.95$ & $-1.84 \pm 1.01$ & $-2.24 \pm 1.20$ \\
\hline Mechanical/Factory worker ${ }^{3}$ & $0.09 \pm 1.09$ & $-1.19 \pm 0.93$ & $-2.06 \pm 0.79$ \\
\hline Other & $-0.57 \pm 1.09$ & $-1.52 \pm 1.01$ & $-1.80 \pm 1.25$ \\
\hline \multirow[t]{2}{*}{ ANOVA test } & $F=2.401$ & $\mathrm{~F}=2.043$ & $\mathrm{~F}=1.297$ \\
\hline & $p=0.037$ & $\mathrm{p}=0.073$ & $\mathrm{p}=0.267$ \\
\hline \multirow[t]{2}{*}{ Tukey Post Hoc test } & $p=0.019^{283}$ & & \\
\hline & $p=0.05^{1 \& 3}$ & & \\
\hline \multicolumn{4}{|l|}{ Religion of household head } \\
\hline All religion & $-0.51 \pm 1.10$ & $-1.67 \pm 1.01$ & $-2.13 \pm 1.25$ \\
\hline Muslim ${ }^{1}$ & $-0.58 \pm 1.01$ & $-1.78 \pm 1.03$ & $-2.22 \pm 1.23$ \\
\hline Christian $^{2}$ & $-0.39 \pm 1.26$ & $-1.42 \pm 0.90$ & $-1.88 \pm 1.33$ \\
\hline Other & $-0.30 \pm 1.46$ & $-1.19 \pm 1.08$ & $-2.30 \pm 0.92$ \\
\hline \multirow[t]{2}{*}{ ANOVA test } & $\mathrm{F}=2.836$ & $F=4.511$ & $\mathrm{~F}=2.098$ \\
\hline & $\mathrm{p}=0.060$ & $p=0.012$ & $\mathrm{p}=0.124$ \\
\hline Tukey Post Hoc test & & $p=0.018^{1 \& 2}$ & \\
\hline
\end{tabular}


Education level of mother

All levels of education

None $^{1}$

$-0.51 \pm 1.10$

$-1.67 \pm 1.01$

$-2.13 \pm 1.25$

Primary

$-0.51 \pm 1.04$

$-1.73 \pm 1.02$

$-2.24 \pm 1.23$

Secondary $^{2}$

$-0.57 \pm 1.17$

$-1.63 \pm 0.95$

$-1.99 \pm 1.28$

ANOVA test

$0.18 \pm 1.34$

$-0.78 \pm 1.16$

$-1.42+1.11$

Tukey Post Hoc test

$\begin{array}{lll}\mathrm{F}=1.745 & F=3.617 & \mathrm{~F}=2.650 \\ \mathrm{p}=0.177 & p=0.028 & \mathrm{p}=0.072\end{array}$

\section{Occupation of mother}

All occupation

$p=0.023^{1 \& 2}$

Housewife $^{1}$

$-0.51 \pm 1.10$

$-1.67 \pm 1.01$

$-2.13 \pm 1.25$

Farmer $^{2}$

$-0.36 \pm 1.09$

$-1.59 \pm 1.01$

$-2.19 \pm 1.21$

Other

$-0.77 \pm 1.03$

$-1.83 \pm 1.00$

$-2.07 \pm 1.37$

ANOVA Test

$-0.51 \pm 1.22$

$-1.58 \pm 0.98$

$-1.98 \pm 1.04$

Tukey Post Hoc test

$F=4.564$
$p=0.011$

$p=0.007^{1 \& 2}$

$\mathrm{F}=1.914$

$\mathrm{F}=0.488$

$\mathrm{p}=0.149$

$\mathrm{p}=0.615$

\section{Age of mother}

\begin{tabular}{lrrr} 
All age group & $-0.51 \pm 1.10$ & $-1.67 \pm 1.01$ & $-2.13 \pm 1.25$ \\
$16-25$ & $-0.57 \pm 1.03$ & $-1.71 \pm 0.97$ & $-2.14 \pm 1.16$ \\
$26-35$ & $-0.37 \pm 1.17$ & $-1.59 \pm 1.05$ & $-2.15 \pm 1.42$ \\
$36-42$ & $-0.73 \pm 1.10$ & $-1.73 \pm 1.05$ & $-2.02 \pm 1.01$ \\
\hline ANOVA Test & $\mathrm{F}=1.816$ & $\mathrm{~F}=0.522$ & $\mathrm{~F}=0.133$ \\
& $\mathrm{p}=0.165$ & $\mathrm{p}=0.594$ & $\mathrm{p}=0.875$ \\
\hline
\end{tabular}

\section{Sex of child}

Both sexes

Boy

$-0.51 \pm 1.10$

$-1.67 \pm 1.01$

$-2.13 \pm 1.25$

Girl

$-0.57 \pm 1.01$

$-1.86 \pm 1.01$

$-2.35 \pm 1.24$

T test

$-0.44 \pm 1.18$

$-1.48 \pm 0.97$

$-1.92 \pm 1.23$

$\mathrm{p}=0.300$

$t=-3.271$

$p=0.003$

\section{Age of child}

All age groups

$12-15^{1}$

$16-19$

$20-23^{2}$

ANOVA test

$-0.51 \pm 1.10$

$-1.67 \pm 1.01$

$-2.13 \pm 1.25$

$-0.34 \pm 1.19$

$-1.58 \pm 1.13$

$-1.91 \pm 1.43$

$-0.65 \pm 0.93$

$-1.73 \pm 0.89$

$-2.16 \pm 1.15$

$-0.57 \pm 1.11$

$-1.72 \pm 0.97$

$-2.41 \pm 1.04$

Tukey Post Hoc Test

$\mathrm{F}=2.412$

$\mathrm{F}=0.709$

$\mathrm{p}=0.493$

$p=0.018$

$p=0.013^{1 \& 2}$ 


\section{Breastfeeding status of child}

All status

Breastfed

Not breastfed

$-0.51 \pm 1.10$

$-1.67 \pm 1.01$

$-2.13 \pm 1.25$

T test

$-0.49 \pm 1.08$

$-1.64 \pm 0.98$

$-2.06 \pm 1.25$

$-0.60 \pm 1.15$

$-1.81 \pm 1.10$

$-2.43 \pm 1.21$

$\mathrm{t}=0.707$

$\mathrm{t}=1.179$

$t=1.995$

$\mathrm{p}=0.480$

$\mathrm{p}=0.239$

$p=0.047$

\section{Immunization status of child}

\begin{tabular}{lrrr} 
All status & $-0.51 \pm 1.10$ & $-1.67 \pm 1.01$ & $-2.13 \pm 1.25$ \\
Fully immunized & $-0.48 \pm 1.12$ & $-1.59 \pm 0.95$ & $-2.06 \pm 1.19$ \\
Partially immunized & $-0.61 \pm 0.97$ & $-2.01 \pm 1.19$ & $-2.48 \pm 1.45$ \\
\hline T test & $\mathrm{t}=0.800$ & $t=2.818$ & $t=2.247$ \\
& $\mathrm{p}=0.424$ & $p=0.005$ & $p=0.025$ \\
\hline
\end{tabular}

\section{Possession of health book}

Yes

$-2.15 \pm 1.28$

No

$-2.02 \pm 1.11$

T Test

$\mathrm{t}=-0.689$

$\mathrm{p}=0.491$ 
Table 7: Mean z-scores after controlling for the confounding effect of child's age

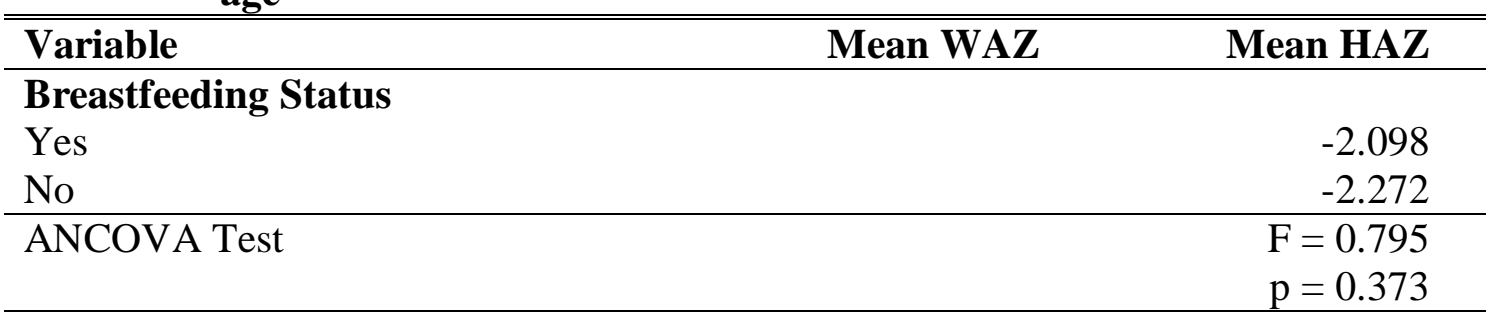

Immunization Status

Fully immunized

\begin{tabular}{rr}
-1.586 & -2.048 \\
-2.033 & -2.545 \\
$\mathrm{~F}=8.964$ & $\mathrm{~F}=7.446$ \\
$\mathrm{p}=0.003$ & $\mathrm{p}=0.007$ \\
\hline
\end{tabular}




\section{REFERENCES}

1. WHO. WHO Global Database on Child Growth and Malnutrition. Program of Nutrition. WHO Document No. WHO/NUT/97.4 Geneva: WHO 1997.

2. Smith $\mathbf{L}$ and $\mathbf{L}$ Haddad Overcoming child malnutrition in developing countries: past achievements and future choices. Washington, DC: International Food Policy Research Institute 2000.

3. UNICEF. The state of the world's children 2006. New York: UNICEF 2006.

4. Pelletier DL, Frongillo EA, Schroeder DG and JP Habicht The effect of malnutrition on child mortality in developing countries. Bull. WHO. 1995; 73(4): 443-448

5. WHO. Physical Status: The Use and Interpretation of Anthropometry. WHO Technical Report Series No. 854. Geneva: WHO 1995.

6. Martorell R, Rivera J, Kaplowitz $\mathbf{H}$ and $\mathbf{E}$ Politt Long-term consequences of growth retardation during early childhood. In: Hernandez $\mathbf{M}$ and J Argente (Eds). Human Growth: Basic and clinical aspects. Amsterdam: Elevier science publishers BV 1992.

7. UNICEF. Annual Report. New York: UNICEF 1999.

8. Chaudry RH Determinants of dietary intake and dietary adequacy for preschool children in Bangladesh. Food. Nutr. Bull. 1984; 6: 24-33.

9. Vella V, Tomkins A, Borghesi A, Migliori GB, Adriko BC and E Crevatin Determinants of child nutrition and mortality in north-west Uganda. Bull. WHO. 1992; 70: 637-643.

10. Mwadime RKN and SL Baldwin Relationship between household access to food and malnutrition in eastern and Southern Africa. East. Afr. Med. J. 1994; 71: $571-579$.

11. Kwale Rural Support Program Baseline Survey in Kwale District, Kenya. 1997.

12. FEWS NET, WFP/VAM, MoA and OP/ALRMP. Kenya Food Security Report. Nairobi: Ministry of Agriculture 2004.

13. Kenya Food Security Steering Group Rapid Food Security Assessment Mission. Report of findings of Team 3 (Taita Taveta and Kwale Districts). Nairobi: Ministry of Agriculture 2004. 
14. WHO. Use and interpretation of anthropometric indicators of nutritional status. Bull. WHO. 1986; 64: 929-941.

15. Hamill PVV, Drizd TA, Johnson CL, Reed RB, Roche AF and WM Moore Physical growth: National Center for Health Statistics Percentiles. Am. J. Clin. Nutr. 1979; 32:607-629.

16. Othowa A, Lijoh B, Mwite $\mathbf{P}$ and $\mathbf{G}$ Okoth Kwale District long rains assessment. Nairobi: Kenya Food Security Steering Group 2005.

17. Kwale District Development Plan Ministry of Planning and National Development. Nairobi: Government Printer 1997-2000.

18. Gibson RS Principles of Nutritional Assessment. New York: Oxford University Press 1990.

19. Ricci JA, Jerome NW, Sirageldin HA, Aly H, Moussa W, Galal O, Harrison GG and A Kirksely The significance of children's age in estimating the effect of maternal time use on children's well-being. Soc. Sci. Med. 1996; 42: 651659.

20. Wandel M and G Holmboe-Ottesen Women's work in agriculture and child nutrition in Tanzania. J. Trop. Pediatr. 1992; 38:252-255.

21. UNICEF. The situation of children and women in Malawi. Lilongwe, Malawi: UNICEF 1987.

22. Government of Kenya Welfare Monitoring Survey III Basic Report. Nairobi: Central Bureau of Statistics, Ministry of Planning and National Development 2000.

23. Gobotswang $\mathbf{K}$ Determinants of the nutritional status of children in a rural African setting: The case of Chobe District, Botswana. Food Nutr. Bull. 1998; 19(1)

24. Vella V, Tomkins A, Nviku J and T Marshall Determinants of nutritional status in south-west Uganda. J Trop Pediatr 1995; 41:89-98

25. Nicholson CF, Thornton PK and RW Muinga Household-level impact of diary cow ownership in Coastal Kenya. Working Paper 2002/08. Ithaca - New York, USA: Department of Applied Economics and Management, Cornell University 2002.

26. Launonon R, Karinpaa A, Marangu $\mathbf{L}$ and $\mathbf{S}$ Minae Rural diary development in Meru: A socio-economic study of small holder milk production, consumption and marketing. Report 8/1985B. Helsinki, Finland: Institute of development studies, University of Helsinki 1985. 
27. Mugo PW A gender differentiated study on impacts of intensive diary farming on socio-economic position of small holder households in Meru District, Kenya. Nairobi, Kenya: National Diary Development Project, Livestock Department and Marketing, Ministry of Agriculture 1994.

28. Ruel MT, Levin C, Armar-Klemesu M, Maxwell D and SS Morris Good care practices can mitigate the negative effects of poverty and low maternal schooling on children's nutritional status: Evidence from Accra, Ghana. Food Consumption and Nutrition Division Discussion Paper 62. Washington DC: International Food Policy Research Institute 1999.

29. Mishra VK and RD Retherford Women's education can improve child nutrition in India. National Family Health Survey Bulletin 2000; No.15.

30. Wasito E and AM Bau Nutritional status among preschoolers and their mothers from selected villages in East Sumba, Nusa Tenggara, Indonesia. Preliminary report. Jakarta, Indonesia: GTZ Seameo-Tropmed Community Nutrition Programme, Universitas Indonesia 1999. 